Wacana Vol. 22 No. 1 (2021): 81-101

\title{
South Borneo as an ancient Sprachbund area
}

\author{
AleXANDER ADELAAR
}

\begin{abstract}
In South and Central Kalimantan (southern Borneo) there are some unusual linguistic features shared among languages which are adjacent but do not belong to the same genetic linguistic subgroups. These languages are predominantly Banjar Malay (a Malayic language), Ngaju (a West Barito language), and Ma'anyan (a Southeast Barito language). The same features also appear to some degree in Malagasy, a Southeast Barito language in East Africa. The shared linguistic features are the following ones: a grammaticalized form of the originally Malay noun buah 'fruit' expressing affectedness, nasal spreading in which $N$ - not only nasalizes the onset of the first syllable but also a *y in the next syllable, a non-volitional marker derived from the Banjar Malay prefix combination ta-pa- (related to Indonesian tor- + por-), and the change from Proto Malayo-Polynesian *s to $h$ (or Malagasy $\varnothing$ ). These features have their origins in the various members of the language configuration outlined above and form a Sprachbund or "Linguistic Area".

The concept of Linguistic Area is weak and difficult to define. Lyle Campbell (2002) considers it little else than borrowing or diffusion and writes it off as "no more than [a] post hoc attempt [...] to impose geographical order on varied conglomerations of [...] borrowings". While mindful of its shortcomings, the current author still uses the concept as a useful tool to distinguish between
\end{abstract}

ALEXANDER ADELAAR is a key researcher in the Sinophon Project at Jan Palacký University, Olomouc, and a principal fellow in the Asia Institute at the University of Melbourne. He is a Fellow of the Academy of the Humanities Australia. His research is on the structure and history of Austronesian languages, with emphasis on varieties of Indonesian/Malay and the languages of Borneo, Madagascar, and Taiwan. He is currently investigating dormant Formosan languages (Taiwan) and the linguistic and migration history of Madagascar. He is also coediting an Oxford Guide to the Malayo-Polynesian languages of Southeast Asia (to appear in 2021). After his retirement from the University of Melbourne in 2009, Adelaar was a research fellow at Institutes of Advanced Studies in Belgium (2010), the Netherlands (2013), the National Museum of Ethnography in Osaka (2011), Tokyo University of Foreign Studies (2014-2015), and the University of Cologne (2016, 2017, 2019). His recent publications include Siraya; Retrieving the phonology grammar, and lexicon of a dormant Formosan language (Berlin: De Gruyter Mouton, 2011) and The Austronesian languages of Asia and Madagascar (co-edited with Nikolaus Himmelmann; London: Routledge, 2011). Alexander Adelaar can be contacted at: s.adelaar@unimelb.edu.au. 
inherited and borrowed commonalities. In the configuration of languages currently under discussion it also provides a better understanding of the linguistic situation in South Borneo at a time prior to the Malagasy migrations to East Africa (some thirteen centuries ago).

\section{KEYWORDS}

Austronesian linguistics; historical linguistics; Borneo; South Borneo; areal linguistics; Malay; Malagasy; Ma'anyan; Ngaju; Banjar Malay.

\section{INTRODUCTION ${ }^{1}$}

In South and Central Kalimantan (South Borneo) there are some unusual linguistic features shared among languages which are adjacent but do not belong to the same genetic linguistic subgroups. These languages are predominantly Banjar Malay (a Malayic language), Ngaju (a West Barito language), and Ma'anyan (a Southeast Barito language). The same features also appear to some degree in Malagasy, a Southeast Barito language in East Africa.

The shared linguistic features are the following ones: a grammaticalized form of the originally Malay noun buah 'fruit' expressing affectedness, nasal spreading, a non-volitional marker derived from the Banjar Malay prefix combination ta-pa- (related to Indonesian tor- + por-), and the change from Proto Malayo-Polynesian (henceforth PMP) *s to $h$ (or Malagasy $\varnothing$ ). The areas in which these linguistic features occur largely overlap and it appears that they form a Linguistic Area. However, the concept of a Linguistic Area (Sprachbund) is notoriously weak (Campbell 2002), and I shall pay it greater attention towards the end of this chapter in Section 4.

This section shall treat the following topics. Section 2 describes the geographical and historical setting of the languages under discussion in very broad terms. Section 3 describes the four linguistic features mentioned above. Some additional evidence is drawn from Kadorih, a Northeast Barito language closely related to Ngaju, and Dusun Malang and Samihim, Southeast Barito languages closely related to Ma'anyan. Section 4 discusses the concept of "Linguistic Area" in light of these features and the topography of the languages in South Borneo and of Malagasy. Some concluding remarks are given in Section 5.

\section{SOUTH BorneO: A gEOgRAPHICAL AND HISTORICAL SETTING}

The people of Banjarmasin speak Banjar Malay, a dialect of Malay showing strong lexical influence from Javanese and local East Barito and West Barito languages. The Banjarese metropole lies close to South Borneo's south coast at the confluence of the Barito and Martapura Rivers. Southeast Barito communities (such as the Ma'anyan and Dusun Witu) are located farther to

1 This publication was supported by the European Regional Development Fund Project "Sinophone Borderlands - Interaction at the Edges" CZ.02.1.01/0.0/0.0/16_019/0000791. I am grateful to Pascal Couderc, Kazuya Inagaki, and Johnny Tjia, for providing me with language materials. 
the north in forested upriver areas, mostly along the banks of the Barito River in the northwestern part of South Kalimantan and in Central Kalimantan. One small group, the Samihim, lives across the Meratus Mountains which run along a North-South axis through South Kalimantan and split it into an eastern and a western part. The Samihim have their settlements close to the coast in the northeastern corner of South Kalimantan Province on the border with East Kalimantan (see Map 1).

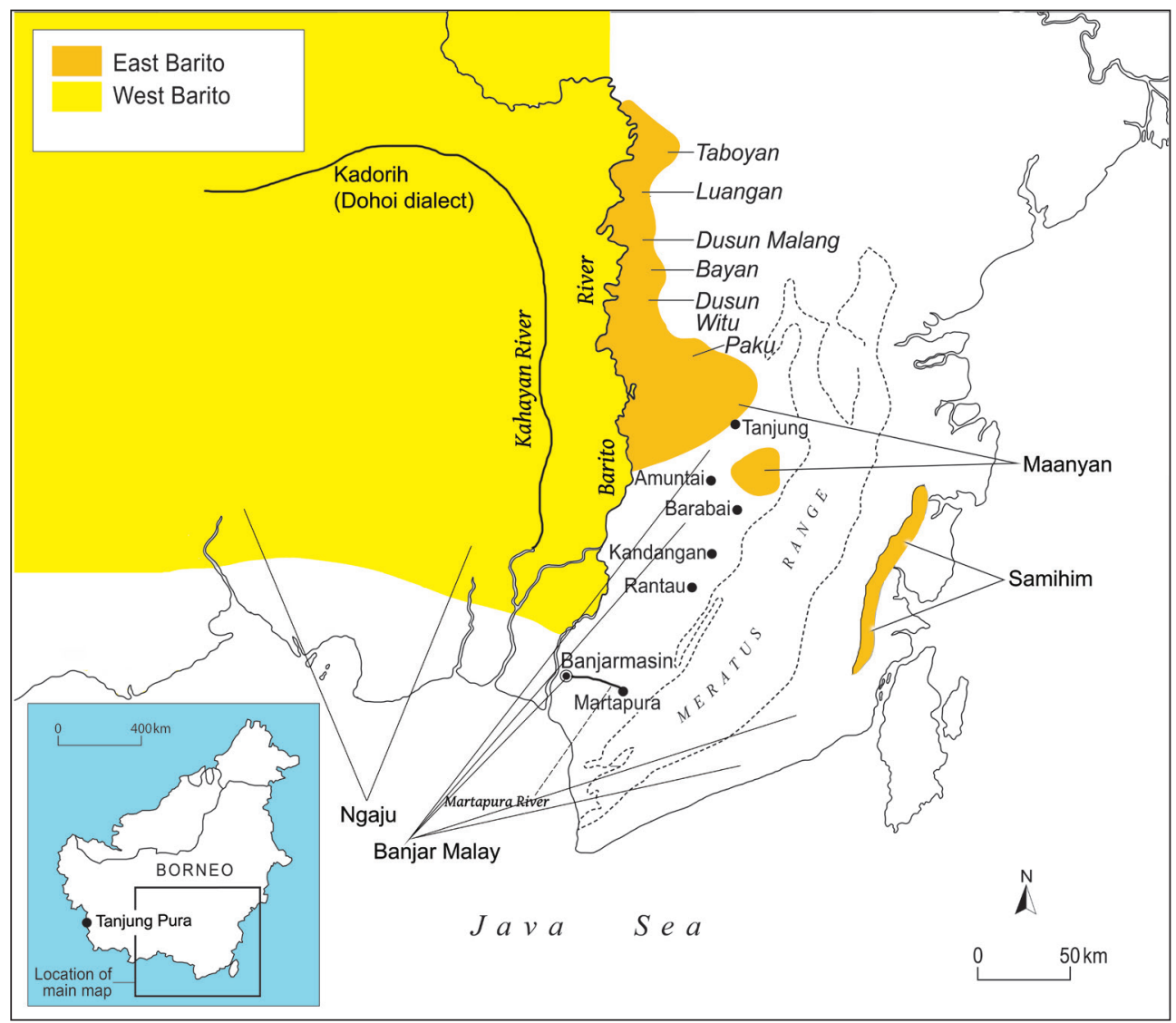

Map 1. Southern Borneo. (Courtesy of the author).

Banjarese Malays and Ma'anyan speakers used to live much closer to one another in the past. The Hikayat Banjar (or Chronicle of the Sultanate of Banjarmasin) ${ }^{2}$ relates that the Banjar dynasty was initially founded in a court centre in Nagaradipa, close to a town called Tanjung (J.J. Ras 1968: 187-192). From there the court moved to places farther downriver including Amuntai and Banjarmasin to reach its final residence Martapura, some 40 kilometres to the east of Banjarmasin. The court palace at Martapura was destroyed after the Banjarese-Dutch War between 1859 and 1865 (Bernard Sellato 2015: 145).

2 This text was recorded in the mid-seventeenth century but refers to many events of a much earlier date. 
From Nagaradipa to the last station at Martapura, these court centres had succeeded one another in a downstream (and basically southward) direction. The underlying reason for moving the court several times was to keep access to the sea, so as to remain commercially viable. This access was often reduced by the accumulation of alluvial material which was brought down by rivers and was blocking harbours along local waterways. It also caused the expansion of coast lines.

The Hikayat Banjar and oral Ma'anyan history also mention that the Ma'anyan people had their original homeland at the mouth of the Sarunai River near Amuntai, one of the intermediate stations of the Banjarese court before its final move to Martapura. According to these accounts, the Ma'anyan and the Banjarese Malays were historically in much greater proximity to one another than they are today, with the Ma'anyan living more to the south whereas the Banjarese Malays had their metropole further to the north, although the precise homeland as well as the historical events and the dates attributed to them need further investigation. The Samihim dialect is a Southeast Barito outlier spoken in the Northeast of South Kalimantan. It is a mutually intelligible variety of Ma'anyan and differs from it in only very minor ways, which is a strong indication that its speakers split off from the Ma'anyan community in very recent times (possibly during sixteenthseventeenth century political tensions, Alfred B. Hudson 1967: 20-24). Among the reasons for the Ma'anyan and Samihim to move farther to the north and northeast was to keep their political and cultural independence from the Banjar Malay metropole, especially when the latter came under increasing Javanese influence (Ras 1968; Hudson 1967: 20-24; Adelaar 2017: 462-467).

Turning to the Malagasy language, the conditions surrounding the migrations of its first speakers to East Africa remain vague. However, in the phonological and lexical history of this language there are strong indications that it had already become a separate dialect before these migrations took place (Adelaar 2017). At any rate, pre-migratory Malagasy had already undergone a slightly different phonological development from other Southeast Barito languages. Moreover, apart from lexical borrowing which is demonstrably recent in the latter, it also underwent a much stronger influence from Malay and Javanese (a prestige language in both Banjar Malay and Malagasy) than the other Southeast Barito languages did. Its development as a separate dialect, or rather sociolect, was apparently the result of an early urbanization process which was also taking place in other towns in Borneo and elsewhere in Southeast Asia (Sellato 2013). The Banjar metropole assimilated large contingents of people from the East- and West-Barito speaking hinterland (Ras 1968). It is likely that speakers of an early form of Malagasy had been involved in this process before they set sail to East Africa. There is clear evidence from autosomal DNA to connect the Malagasy to the population of Banjarmasin city (Nicolas Brucato et al. 2016). A likely scenario is that in early times Southeast Barito speakers living relatively close to the Banjar Malay metropole were gradually becoming integrated into the metropolitan population. Before that 
process had taken its full course, some of them migrated to East Africa, whereas others continued to assimilate to the Malay-speaking nucleus of Banjarmasin, eventually becoming speakers of Banjar Malay and identifying themselves as Malays. This would explain the autosomal DNA signal linking the people of Madagascar to the people of Banjarmasin city. ${ }^{3}$

Aside from the socio-historical and human genetic evidence, the linguistic evidence alone is already compelling enough to link the Malagasy language historically to the Linguistic Area I am presenting here.

\section{LINGUISTIC EVIDENCE}

In this section I discuss the evidence of four linguistic features. Each of these originated in one or some languages of southern Borneo and spread into others through contact.

\subsection{Grammaticalization of *buah}

Ngaju, Ma'anyan, and Malagasy have a related set of verbs expressing that some activity was done correctly, hit the mark and/ or was successful. In Ngaju the verb is buah 'hit, affected', and in Ma' anyan it is wuah '1. affected, hit; 2. correct, hitting the mark'. Merina Malagasy has a grammaticalized verbal prefix vua- indicating that the activity expressed by the host verb was carried out successfully. Other Malagasy dialects have this verbal prefix as well a free verb form vua, which means 'hit, affected' and is more directly comparable to Ngaju and Ma' anyan buah. These words and prefix look suspiciously like PMP *buaq 'fruit' (+ associated meanings, see Blust and Trussel online). However, they are not regular reflexes of this etymon but were borrowed from Malay, more particularly from the Malay that developed in Banjarmasin or one of its urban predecessors in southern Borneo. Banjar Malay buah means 'fruit'. However, it has also become the root of a verb indicating that some activity was successful, which is mam-buah- $i$ 'succeed, give birth to' (Abdul Djebar Hapip 2006). Most likely, it is this verb with the meaning 'succeed' which generated the buah and wuah forms in the various Barito languages to the north.

The instances (1), (2), and (3) illustrate Ma'anyan wuah 'hit, affected' (Adelaar n.d.). ${ }^{4}$

3 The specifically gender-related mitochondrial and Y-chromosome DNA of the Malagasy people show more distinct affiliations with eastern Indonesian and Ma'anyan ancestry respectively (Brucato et al. 2016).

${ }^{4}$ I collected fieldnotes between 2010 and 2019 in Tamiang Layang, East Barito Regency, Central Kalimantan, Indonesia. I am very grateful to my language consultants, who were Mr Kastian Wahid (born 1946), local radio presenter and former civil servant in the local Department of Education and Culture, and Mr Wahatin Siuk (born 1945), former Head of the local branch of the National Education Department, both in Tamiang Layang. 
(1) Ware aku nampaley hang repuan, eh, gare wuah usin! let I set a trap in kitchen hey who knows hit cat

'Let me set a trap in the kitchen: hey, I might even catch the cat!'

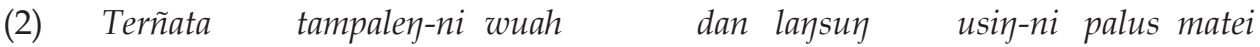
apparently trap-his hit the target and right away cat-his then die 'Apparently the trap did its job and his cat died right away.'

(3) Wuah inun hañu Gayuhan?

affected (by) what you (proper name)

'What's the matter with you, Gayuhan?'

August Hardeland $(1858,1859)$ gives the examples (4) and (5) of Ngaju buah 'good, right; hit'.

(4) Buah augh-m

correct say-your

'What you said is right.'

(5) Handak ikau omba aku? Buah!

want to you with I correct, on target

'Would you like to come with me?' 'Sure!'

In (6) a reduplicated form of buah is used as an adverb expressing caution.

(6) Bua-buah augh-m, bela ikau inekap

careful say-your if not, you get.slapped

'Be careful what you say, or you might get whacked!'

Incidentally, this buah is also found in Kadorih, a Northwest Barito language closely related to Ngaju. ${ }^{5}$ This language has also two reflexes of PMP *buaq (Kazuya Inagaki 2008). One, bua 'fruit', is a regularly inherited reflex of *buaq. The other, buah 'right, indeed, on target', must have been borrowed from Banjar Malay (whether directly or via Ngaju or another local West Barito language). Inagaki (2008: 121) gives the instance (7).

$$
\begin{array}{ll}
\text { Orih ijo buah } \\
\text { ANAPH NMZ on.target }
\end{array}
$$

'That is the right one.'

As pointed out above, Malagasy has both a prefix vua-carrying a resultative meaning, and a free form vua 'hit, affected', which only occurs in southern and southwestern dialects such as Salakava, Vezo, and Antandroy. As indicated above, vua- and vua directly reflect a Banjar Malay source form buah.

\footnotetext{
${ }^{5}$ Kadorih is a dialect of Dohoi spoken in the Upper reaches of the Kahayan River, Central Kalimantan. Another name for it in the literature is Ot Danum.
} 
Resultative derivations often have a passive meaning with emphasis on the result: the act was intended by the agent and has been completed. Compare some examples of the resultative prefix in Merina Malagasy in (8) (Janie Rosoloson and Carl Rubino 2011).

$\begin{array}{llll}\text {-fidi } & \text { 'choosing' } & \text { vua-fidi } & \text { 'elected' } \\ & & \text { vua-räkitră } & \text { 'preserved' } \\ \text { vua-tèri } & \text { 'forced' } \\ \text { hàja } & \text { 'respect' } & \text { vua-hàja } & \text { 'respected' } \\ \text { fâritra } & \text { 'fence' } & \text { vua-fâritră } & \text { 'demarcated' }\end{array}$

(Rasoloson and Rubino 2011: 477)

Fukuntàni èfatră nu vua-kàsiǩ̆ ny rànu community four FOCUS RESULT-to.affect ART water

'Four communities were affected by the water.'

(Rasoloson and Rubino 2011: 477)

In southern and western Malagasy dialects it is still predominantly a free form, even if it is often attached to a following noun by a linker $-\mathrm{N}-$. Compare the western Malagasy instances in (9) taken from Noël Gueunier's dictionary (Gueunier n.d.).

(9) vùa 'hit, affected (by)'

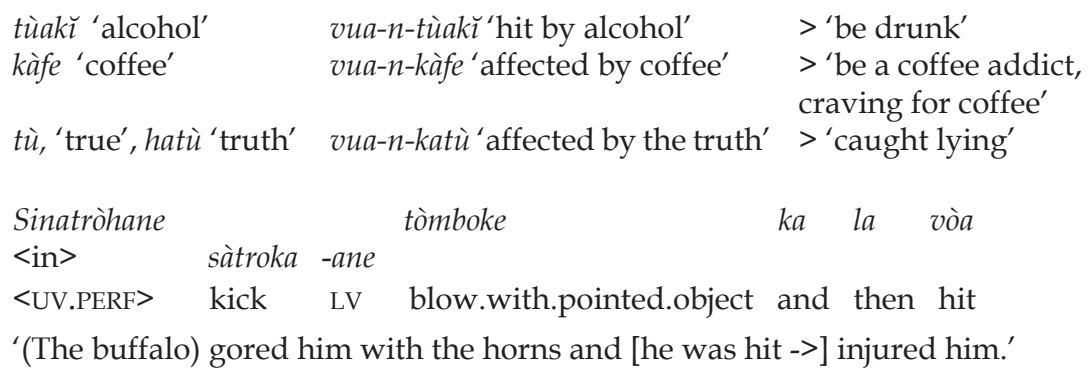

tsinatòko fònja bènge zay la la vòa vozobè
$<$ in> tsàtoke ${ }^{2}$ vòzo be <UV.PERF> stick,attach 1s.GEN noose goat ANAPH and then hit neck big 'I threw the noose over the goat, [and the neck got caught >] and caught it by the neck.'

$\begin{array}{lllll}\ddot{n} y & f a & n i-v o ̀ a & \text { tsy vòa kòa } \\ \text { ART } & \text { already } & \text { PST-hit } & \text { not hit again }\end{array}$

'Those who were already hit won't have it happen to them again.' (Masikoro dialect) 
The verb is also recorded in Frederick de Houtman's seventeenth-century's wordlist. ${ }^{6}$ See (10).

(10) sy woe'a / si wual 'missed, failed to hit' (17th c. Dutch 'mis oft niet gheraeckt') woa handack/wuahandak/ 'to hurt' (17th c. Dutch 'quetsen')

The final $h$ in Ngaju buah and Ma' anyan wuah is identical to the final $h$ in Banjar Malay. It shows that these forms are reflexes of Banjar Malay buah rather than of PMP *buaq. If they had been regular reflexes of the latter they would have had a final ?, as ? is the regular reflex of PMP * $q$. And as a matter of fact, Ngaju and Ma'anyan do have reflexes of PMP *buaq with the expected final ?. Ngaju bua? and Ma' anyan wua? do exist but they have the predictable (and inherited) meaning 'fruit'.

The Malagasy verb vua 'hit the mark, correct' and verbal prefix vua'(+resultative)' are no doubt also reflexes of Banjar Malay buah. However, the language also has a noun vua 'fruit': although synonymous with vua and vua-, it must be an inherited reflex of PMP *buaq. The noun vua 'fruit', the verb vua 'hit the mark, correct', and the verbal prefix vua-'(+resultative)' are all formally identical, caused by the fact that in Malagasy phonological history both *-? and *-h were lost (whereas in Ma' anyan and Ngaju they remained distinct as $-?$ and $-h$, and in Kadorih as $-\varnothing$ and $-h)$.

\subsection{NASAL SPREADING}

Robert A. Blust (2013: 238-239) briefly discusses nasal spreading in Ngaju and other Bornean languages. The phenomenon is also observed in Ma'anyan. If the initial consonant of a word with an intermediate $y$ (palatal semivowel) is nasalized, the latter as a rule also becomes nasalized and changes into $\tilde{n}$, for example, prefixation of $N$ - to the Ma'anyan root wayat yields mañat 'to pay'. In Malagasy, such nasal spreading must also have occurred but is no longer in operation. It has become difficult to spot because it became fossilized and both * $\tilde{n}$ and ${ }^{*} n$ merged to $n$. However, it is still retrievable through historical analysis. In Banjar Malay the phenomenon only appears in one isolated case.

\section{Ngaju}

For Ngaju, Blust (2013: 238-239) gives the derivations as in (11).

\begin{tabular}{|c|c|c|c|}
\hline kayu & $\begin{array}{l}\text { 'wood; firewood' } \\
\text { 'salt' }\end{array}$ & 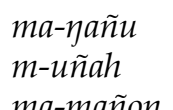 & $\begin{array}{l}\text { 'to gather firewood' } \\
\text { 'to salt something' }\end{array}$ \\
\hline & 'umbrella' & ma-mañoท & h an umbrella \\
\hline
\end{tabular}

${ }^{6}$ This list represents Northeast Malagasy as spoken in the late sixteenth century in Antongil Bay (Houtman 1603).

7 Sy / si / 'not'; handack / handak/ 'wounded? hit?' (Houtman 1603). 
Ma'anyan

Ma'anyan has the instances as in (12) (source as indicated).

\begin{tabular}{|c|c|}
\hline wayat 'paying' & mañat 'to pay' \\
\hline hиyu 'ordering' & 'to order' \\
\hline ayak 'inviting' & $\eta$-añak 'to invite' \\
\hline kuyum 'mouthful' & $\begin{array}{l}\text { ๆuñum 'to mouth without } \\
\text { swallowing (tobacco)' }\end{array}$ \\
\hline $\begin{array}{l}\text { hayay 'a pity, waste' } \\
\text { (Malay) moyay } \\
\text { 'great-grandparent' }\end{array}$ & $\begin{array}{l}\text { na-hañay 'let go waste' } \\
\text { muñay 'great-great- } \\
\text { grandfather' }\end{array}$ \\
\hline
\end{tabular}

(G.S. Rubay et al. 1997)

(Rubay et al. 1997)

(Rubay et al. 1997)

(Rubay et al. 1997)

(Adelaar n.d.)

(Hudson 1967)

'great-grandparent'

\section{Banjar Malay}

Banjar Malay does not show nasal spreading nasalizing a following $y$, except for one possible example in Abdul Djebar Hapip's (2006) dictionary and W. Kern's (n.d.) wordlist of Banjar Malay, in which we found the following variant forms samua'an, samuya'an, samuña'an 'all, everybody'.

\section{Malagasy}

In Malagasy, nasal spreading changing a following * ${ }^{*}$ into $\tilde{n}$ (a palatal nasal) is only shown in historical hindsight (Adelaar In press). In modern Malagasy dialects, historical palatal nasals have merged with coronal nasals, and any manifestations of nasal palatalization in the current dialects are recent and non-phonemic developments. Moreover, in the Merina dialect (taken as the default form of Malagasy in this article), * $\tilde{n}$, * $\eta$, and * $n$ have all merged to a single $n$ phoneme. Although modern Malagasy varieties no longer have $\tilde{n}$, some entries in Houtman (1603) still maintained one. They do so in meynja / mèña/ 'red' and mang'anjarts / may-ànats / 'to teach', and also in fanjou / fânu / 'turtle', fanjing / fâñì/ 'dizzy', and avoenji / wùñi/'secretly'. (Note that in Houtman's Dutch based spelling $j$ stands for a palatal nasal).

In mena 'red', the intervocalic $n$ is the historical result of nasalization of * $y$ (reflecting an earlier PMP *R) under the influence of the preceding adjectival prefix *m(a)-, see (13).

(13) $\quad$ PMP *ma-iRaq 'red'

$>$ Proto Southeast Barito *m-عya? 'red'

$>$ Dusun Malang meya? (Johnny Tjia n.d.), Samihim mea? (Adelaar n.d.)

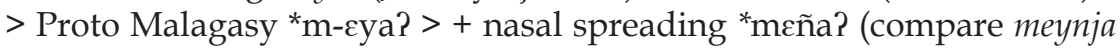
in Houtman 1603) > current Malagasy mèna 'red'

Another root that seems to have undergone nasal spreading, although in this case the historical (and hypothetical) Malay source *(h)ayar (> modern Malay ajar 'studying/teaching') has currently an affricate $j$ instead of a semivowel $y$, see (14). 
Old Malay (?) *(h)ayar 'learning/teaching'

$>+$ fortition of *y in later Malay: *hajar: məy-ajar 'teach, bə-l-ajar 'study'

$>$ (via borrowing) into Proto Malagasy *ayaT 'learning/teaching'

$>$ *mi-añaT 'to study', *man-añaT 'to teach'

$>$ Merina Malagasy ànatră (with fossilized root nasal and loss of palatalization) 'learning/teaching'; mi-ànatră 'to study', manànatră 'to teach'

More speculatively, nasal spreading could also be seen in Merina Malagasy mi-aniana 'to take an oath, swear', which could be a borrowed reflex of Malay aniaya 'injustice, oppression; wrong inflicted by the strong on the weak'. Malay aniaya is ultimately borrowed from Sanskrit. In mi-aniana the second $n$ may have been caused through nasal spreading under the influence of the initial one, see (15).

$$
\begin{aligned}
& \text { (Old) Malay aniaya (< Sanskrit) } \\
& \text { borrowed into early Malagasy as *aniaña } \\
& \text { modern Malagasy aniana }
\end{aligned}
$$

While not inconceivable, the semantic connection between Malay aniaya and Malagasy aniana remains admittedly uncertain.

\subsection{THE NON-VOLITIONAL PREFIX tapa-/ tafa-}

Ngaju and Banjar Malay share a prefix tapa- marking non-volitional action. It is matched by Malagasy tafa-, which has a comparable function. In Ma' anyan, instances reflecting *tapa- are sporadic.

\section{Banjar Malay}

In Banjar Malay, ta-pa-appears to be an unproductive prefix combination. The available Banjar Malay sources do not mention its existence explicitly, but it appears in some derivations scattered through Abdul Djebar Hapip's (2006) dictionary. Abdurahman Ismail et al.'s grammar sketch of the Bukit subdialect does treat ta-pa-derivations explicitly $(1979$ : 44, 48). The combination ta-pa- expresses that something has happened by accident, erroneously or unintentionally. Phonologically and morphologically, this form can easily be analysed as a combination of the non-volitional prefix $t a$ - and the applicative/ causative prefix $p a-$, which are regular reflexes of respectively Proto Malayic *tAr- and *pAr- (Adelaar 1992: 150-163). In the latter prefixes, *A stands for an undecided * $ə$ or *a. The examples in (16) are from Abdul Djebar Hapip (2006). 
(16) ba-hurup 'to exchange; to buy'

anak'child', ba-r-anak 'have a baby's

minantu 'child-in-law', ba-minantu

'have a child-in-law'

rukuy 'harmonious, fitting' ta-pa-hurup 'to be exchanged by accident, erroneously'

ta-pa-r-anak 'having a baby without being prepared'

ta-pa-minantu 'to get a child-in-law'

ta-pa-rukuy 'spot on, very fitting'

Additional instances are found in the Bukit subdialect of Banjar Malay, for example, Abdurahman Ismail et al. (1979: 48), see (17).

hual 'problem, issue'

ta-pa-hual 'becoming a problem because of lack of previous planning'

Although ta-pa-seems to be no longer productive in Banjar Malay, the fact that this prefix combination can be derived from two other verbal prefixes singles this language out as the probable source of ta-pa-.

\section{Ma'anyan}

Otto Christian Dahl (1951: 179) points out that, according to H.H. Sundermann (1913), Ma'anyan has the corresponding set tapa-/tapo-/ tapi-expressing nonvolition, as shown in the example tapo-anrä 'fallen asleep; overcome by sleep'. It might have fallen in desuetude, as I did not come across instances of ta-paduring my research in Central Kalimantan, and Darmansyah H. Gudai (1985) does not mention it in his grammar. However, among his sample sentences illustrating the accidental "passive" prefix $t a-$, there is one example that does appear to have the prefix combination. In the following sentence, ${ }^{10}$ tapaindiq is interpreted as if it consists of $t a-+$ a root paindiq 'to see', but this root is in fact indiq, ${ }^{11}$ and the structure of the derivation is ta-pa-indiq (Gudai 1985: 225), see (18).

$$
\begin{aligned}
& \text { ulun yeruq ta-pa- indiq daya-ku ipa-nyiuk } \\
& \text { person }^{12} \text { the accidental.passive- see by-me REc-kiss } \\
& \text { 'I accidentally saw the man and woman kissing each other.' }
\end{aligned}
$$

\footnotetext{
8 Abdul Djebar Hapip (2006) classified this form under the entries ranak and paranak. In my analysis ta-pa-ranak is immediately derived from bar-anak' 1 . give birth; 2 . have a child'. The latter in turn is derived from a basic root anak 'child'; the appearance of $-r$ - in baranak and taparanak is regular between vowels on morpheme boundaries. I consider ta-pa-forms to be directly derived from $b a$-verbs, an assumption not made by Abdul Djebar Hapip or Abdurahman Ismail et al. (1979).

9 Compare also Banjar Hulu Malay hual 'problem, dispute, fight' and ba-hual 'to dispute, have a fight'.

${ }^{10}$ Morphological parsing and glossing are slightly different from the original source.

${ }^{11}$ Adelaar (n.d.), Rubay et al. (1997), and other sources have indi? 'to see'.

${ }^{12}$ Gudai translates ulun as 'man', but it basically means 'human being, person', and the gloss 'man' is semantically unduly narrow and awkward in the context of the sample sentence.
} 


\section{Malagasy}

Malagasy has a productive prefix tafa-, which matches Banjar Malay ta-fa- in form and meaning, as is shown in the two instances as in (19) and (20).

tafa-tèli-ku ni vàtu
INVOL-swallow-by.me ART stone

'I swallowed the stone by mistake.' (Dahl 1951: 216)
tafa-vèrină t-ètu Antananarìvo $\mathrm{Ni}$ Filùha
INVOL-return PST-there Antananarivo ART President, Head (proper name)
'President Zafy happened to come back to Antananarivo.' (Rasoloson and Rubino 2011: 478)

Note that the first of these sentences is undergoer-oriented whereas the second one is not. Dahl (1951:216) considers both vua- and tafa- passive prefixes, but there is good evidence to conclude that passive voice is not central to their meaning. Nor is it central to the meanings of tapa-and $t V p V$ - in other Barito languages or in Banjar Malay.

\section{Ngaju}

In his Ngaju grammar, Hardeland $(1858,1859)$ mentions a non-volitional tapaprefix, but he also notes that instances were few. Among the ones I found in his grammar and dictionary of Ngaju are the instances as in (21).

(21) tiroh-kantok 'sleep; sleeping'
(paranjur)

malanjin 'slip out' tapa-tiroh 'inadvertently fall asleep' tapa-ranjur 'make an overhasty manoeuvre, be manipulated, seduced' tapa-lanjin 'slip out by accident (for instance, of one's hand)'

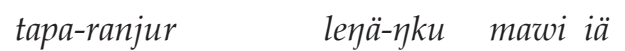
INVOL-do.overhasty hand-my hit him 'I accidentally hit him with my hand.'

mikäh aku tapa-tiroh, pisik aku if,maybe I INVOL-sleep wake.up I

'If I fall asleep, wake me up!'

\section{Other Barito languages}

This prefix is incidentally also found in some other Barito languages. Johnny Tjia (n.d.) has the single example from Dusun Malang, in which tapa- has a resultative meaning, see (22).

(22) kanre 'sleep' > m-anre 'have a sleep'

$>$ pa-kanre (CAUS-sleep) 'put to bed'

$>$ tapa-kanre (RESULT-sleep) 'fall asleep' 
Inagaki (2006: 45) discusses a prefix $t V p V$-indicating non-volition in Kadorih. In this prefix, $V$ stands for $a$ or $o$. Inagaki gives the derivations as in (23), which are all undergoer-oriented.
tVp V-kosak
$t V p V$-dia
tapa-kosak 'to be cooked unexpectedly'
$t V p V$-darou tapa-dia门 'to be elevated' topo-darou 'to be overdone'

\subsection{THE CHANGE FROM PMP *s TO $h$ OR $\varnothing$}

PMP *s regularly became * $h$ in Southeast Barito languages. The change did not take place in West Barito languages. In Ma'anyan, we find $h$ in all positions of the word; in Malagasy *s developed further to Ø. Compare the words in (24).

\begin{tabular}{|c|c|}
\hline $\begin{array}{l}\text { *sungay 'river' } \\
\text { *pusuq 'heart' } \\
\text { *sampay 'enough' } \\
\text { *pusəj 'navel; centre' } \\
\text { *lawas 'long time' }\end{array}$ & $\begin{array}{l}\text { hüey } \\
\text { liam/poho }{ }^{13}<{ }^{\prime} \text { lian }^{14} \text { 'hole' + * } \text { puhu 'heart' }^{\prime} \\
\text { hampi, pi 'to, until' } \\
\text { puhet 'navel' } \\
\text { lawah }\end{array}$ \\
\hline
\end{tabular}

However, in both languages, $s$ was re-introduced via Malay loanwords. In Ma'anyan this must have happened much later than in Malagasy, notwithstanding the fact that the early Malagasy speakers became almost totally isolated from speakers of other Indonesian languages after their migration(s) to East Africa (presumably in the seventh century CE). On the other hand, although Ma'anyan speakers continued to live alongside speakers of Banjar Malay in southern Borneo, they exhibit fewer cases of re-introduced $s$ than Malagasy (Adelaar 2017: 463, 466).

It clearly shows that the change from *s to $\varnothing$ only happened for a relatively short period among the early Malagasy speakers, who already from a very early stage were undergoing the effects of Malay urbanization, whereas it lasted for a much longer time among speakers of Ma'anyan and other Southeast Barito languages, who continued to live more isolated in rural and forested areas further north. From the outset they must have been less exposed to influence from (Banjar) Malay and other Indonesian languages than the early Malagasy once were, and they must have remained so until relatively recently. As a result, the sound-change from *s to $h$ continued undisturbed for a much longer time, and current Southeast Barito languages in southern Borneo show many more instances of it than Malagasy does of * $>\varnothing$. Compare the words in (25) and (26).

\footnotetext{
${ }^{13}$ Occurring in the so-called "Holle lists" compiled at the turn of the twentieth century (W.A.L. Stokhof 1986: 80).

${ }^{14}$ The initial $l$ points to borrowing: historical *li sequences are as a rule reflected as $d i$ in Ma' anyan.
} 


\begin{tabular}{|c|c|c|c|}
\hline \multirow[t]{5}{*}{ (25) } & Malay & Ma'anyan & Malagasy \\
\hline & ${ }^{*} \mathrm{~S}$ & $s$ & $s$ \\
\hline & sambaw 'cargo ship' (Old Malay) & sambaw 'celestial ship' & sàmbu 'large ship' \\
\hline & sadia 'already; it is true' (< Sanskrit) & sadia 'already; ready' & satrìa 'because' \\
\hline & isi 'content, flesh' & isi 'content' & $\begin{array}{l}\text { m-isi ' to have; exist; } \\
\text { to contain' }\end{array}$ \\
\hline \multirow[t]{13}{*}{$(26)$} & Malay & Ma'anyan & Malagasy \\
\hline & $*_{S}$ & $h$ & $s$ \\
\hline & $\begin{array}{l}\text { sakhāy, sakhāyam 'servant, } \\
\text { companion' (Prakrit > Old Malay?) }\end{array}$ & $\begin{array}{l}\text { hake 'foreigner; } \\
\text { Muslim' }\end{array}$ & sakaiza 'companion' \\
\hline & $\begin{array}{l}\text { salah 'wrong' (in salah-satu: } \\
\text { 'undetermined') }\end{array}$ & hala 'wrong' & salasàla 'undetermined' \\
\hline & gasin 'spinning top' & gahin & hàsina \\
\hline & sakit 'sick, ill; hurt' & hakit 'difficult' & $\begin{array}{l}\text { sahirana 'troubled, } \\
\text { unmoved, embarrassed' }\end{array}$ \\
\hline & k/asih 'love' & ahi 'compassion' & àsi 'veneration' \\
\hline & nusa 'island' & & nùsi \\
\hline & sira 'salt' (obs.) & & sira \\
\hline & sadikit 'a bit' & $\begin{array}{l}\text { hadikit'scraps of } \\
\text { rattan' }\end{array}$ & - \\
\hline & sayay 'pity; love' & hayay & - \\
\hline & soal 'problem, question' (< Arabic) & hual & - \\
\hline & mahesa 'buffalo' (Old Malay) & eha 'animal' & - \\
\hline
\end{tabular}

In Banjar Malay PMP *s generally remained *s, but there are a fair number of exceptions, for example, in (27).

${ }^{15}$ The present-day Indonesian/Malay cognate is sakay, described by R.J. Wilkinson (1959) as "subject; dependent. Of subject peoples in contr[ast] to the ruling race; [...]". The term Sakai also designates certain divisions among the Orang Asli in West Malaysia but has acquired a disrespectful connotation. Dahl (1951: 102) derives sakaiza from a Prakrit source form sakhāyam, in which the final $m$ had a weak pronunciation. He assumed that Indic loanwords were borrowed directly from Indian sources, although it is clear for several reasons that they were borrowed via Malay and Javanese (Adelaar 1989: 32-35 and footnote 35). It is also likely that at some stage the derived accusative form sakhāyam and plural form sakhāyah 'friends; assistants, companions' were extant in Old Malay. 


Various sources
*s
Indonesian saja 'just, only'
Indonesian soal (< Arabic su'āl) 'problem, question'
Indonesian seret, monyeret 'to drag, pull'
Indonesian seyal 'panting, out of breath'
Indonesian salain itu 'also, apart from that'
Indonesian sampai 'until'
Banjar Kuala Malay sidin '3rd person singular polite'
Javanese sampéyan '2nd person (high register)'
Banjar Hulu Malay sagan 'for'

Banjar Malay

h

haja

hual, sual

hirit

hinal

Banjar Hulu Malay halian ${ }^{16}$

hampay

Banjar Hulu Malay hidin

hampian, pian 'Sir'

(variant form) hagan

\section{The Linguistic AREA CONCEPT}

The areal features discussed in Section 3 can be traced to several sources. It has been demonstrated that Ngaju (and Kadorih) buah and Ma' anyan wuah are not inherited but loanwords from Banjar Malay. The same applies by implication to Malagasy vua-/vua, although in this language there is no longer a phonological distinction between the inherited form vua 'fruit' and the borrowed grammatical word vua or its prefixed counterpart vua-.

It is also likely that Banjar Malay ta-pa- lies at the origin of Ngaju, and Dusun Malang tapa-, Ma'anyan tapa-/ tapo-/ tapi-, (Kadorih $t V p V-$ ), and Malagasy tafa-, based on two assumptions. On the one hand, these disyllabic prefixes do not as such reflect PMP. On the other, they can be explained in Banjar Malay as the combination of two other existing prefixes $t a$ - and $p a$ - which are inherited from PMP and reflect *tar- and *paR- respectively. That explanation would not do for Ngaju tapa- (or Kadorih $t V p V$-), because in Ngaju, * $\mathrm{R}$ would have become $h$, and *a would have become a schwa, or for Malagasy tafa-, Ma' anyan tapa-/ tapo-/tapi-, and Dusun Malang tapa-, because in these languages, * $\mathrm{R}$ should have become $y$ (Malagasy $z$ ) or $\varnothing$ and *a should have changed to $i$. Moreover, in Banjar Malay, $p a$ - is in a regular paradigmatic relationship with $b a-$, with $b a$ - occurring in intransitive verbs, and $p a$ - emerging instead of $b a$ - whenever an original $b a$-form is either transitivized (for example, ba-hurup 'to exchange' versus ta-pa-hurup ' to be exchanged by accident') or nominalized (as in ba-padah 'to tell, inform' versus pa-padah or pa-padah-an 'advice'). In Barito languages there is no such paradigmatic relationship between the second syllable in tapa- (or tafa-, $t V p V$-, et cetera) and other prefixes.

On the other hand, nasal spreading changing a *y in the following syllable to $\tilde{n}$ is a Ngaju and Ma'anyan phenomenon. It had no real impact on Banjar Malay, and it is very unlikely to have originated in that language. It is also sporadic in Malagasy. It must have originated in Ngaju or Ma'anyan, or, as may be the case, both languages were affected by the phenomenon as part of an areal feature spread more widely in Borneo. Blust (2013: 239) also notices

\footnotetext{
${ }^{16}$ The vowel correspondence with Standard Malay (Indonesian) lain 'other' is irregular. Abdul Djebar Hapip (2006) gives Banjar Malay (Hulu dialect) lian 'also, too' and halian 'also, other than that'. It is possible that the vocalization of halian is the result of interference from Javanese, as the latter has liya 'other'.
} 
this extreme form of nasal spreading in Narum. However, this language is spoken in a rather different part of the island (northern Sarawak in North Borneo). Moreover, in Narum the spreading has affected a following $l$, not $y$. Both factors militate against a connection between the nasal spreading in Narum and that in Ngaju and Ma'anyan.

Finally, the change from *s to $h$ must have originated in the East Barito language group. It defines the Southeast Barito subgroup to which Ma'anyan, Dusun Malang, and Malagasy belong, even if these languages have meanwhile re-introduced $s$ though lexical borrowing. The change from *s to $h$ is more widespread and occasionally is also shown in Jakarta Malay (Adelaar 1992: 93) and other Malayic varieties spoken along the coasts of the South China Sea, such as Bangka Malay (Bernd Nothofer 1995). Nothofer argues that it is an exclusively shared innovation inherited from a common stock language which was ancestral to these two Malayic varieties. They would form a distinct subgroup of Malayic spoken in the "Southwest corner" of the South China Sea. However, the change is represented rather unevenly among the languages in question (Adelaar 2004), and - as we saw - it is also shown in South Borneo (and Malagasy). Moreover, in the Southeast Barito language group it can be shown to have been a sound change which was almost unconditional and regular at least in the early stages of its existence. The change would be more suitably explained as an exclusively shared innovation defining the Southeast Barito language group, which spread later on as an areal feature outside that group and affected to a more or less degree various Malayic languages in the southwest corner.

An impression which comes through very clearly is that, whereas Banjar Malay shares three of the four features discussed above, their impact is less strong in this language than it is in other members of the assumed Linguistic Area. Banjar Malay is clearly the source of buah/vua/vua- and tapa-, but Banjar Malay buah has never been grammaticalized to the same extent as it did in Barito languages. And while Banjar Malay is also the source of $t a-p a-$, this combination seems to be only a marginally represented in Banjar Malay (although this may be due under-reporting in the grammar sketches). As to the change from *s to $h$, it is at best a sporadic change in Banjar Malay.

\subsection{The STAtus OF THE CONCEPT Linguistic AREA}

Campbell (2002) makes it clear that the notion of a Linguistic Area has been a problematic one ever since it was formulated by Nikolai S. Trubetzkoy (1928). To begin with, the latter, in his endeavour to define it, made no distinction between common features that are inherited and those that are attributable to diffusion. However, more recent scholars usually consider a Linguistic Area one which is based on common features attributable to diffusion only.

There seems to be no authoritative definition of a Linguistic Area. Campbell discusses the various conditions which have been mentioned in the various definitions of the concept: (1) there should be more than two languages involved; (2) these languages should belong to at least two different language 
families; (3) there should be several shared features; (4) these features should not only be lexical but also phonological, morphological, grammatical, and/ or syntactic; (5) the features should constitute a bundling of isoglosses, that is, they should cover the same geographical area; (6) the languages sharing these features should be spoken in a contiguous area. Campbell falsifies almost all of these criteria. According to him, it is sufficient if only two languages are involved, and they can belong to the same language family. In fact, the languages constituting the Balkan "Sprachbund" are all Indo-European, and it is not even possible to determine objective criteria regarding how different the languages should be from one another. Furthermore, it is already sufficient if the languages in question share one common feature, based on the assumption that the typological weight of features is more important than their number. The relevant features or isoglosses do not need to bundle: in fact, they hardly ever do, as is obvious from a glance at isoglosses ${ }^{17}$ on virtually every dialect map. Practically, this means that not all features are necessarily shared by all languages involved, and conversely, the occurrence of some features could extend into areas beyond those occupied by the languages involved. Finally, it is no precondition that the languages involved neighbour one another: two languages might occupy the same area, or a language no longer spoken might still influence other languages which have developed from it (a so-called "vertical contact", as with Latin influencing Italian or French and so forth), or a prestige language from another part of the world may have a converging influence on various languages elsewhere ${ }^{18}$ (as with Latin influence on English, or, in the context of Austronesian languages, 500 years of Portuguese influence on the languages of Timor Leste $\left.{ }^{19}\right)$.

(Campbell does not discuss the sixth condition claiming that common features should not only be lexical but also of a more structural linguistic nature. However, this is hardly a problem in the current discussion as the features under scrutiny are all grammatical). ${ }^{20}$ Campbell is not impressed by the Linguistic Area concept. The only use he has for it is an indirect one, as it culls any similarities resulting from contact and diffusion: once these are out of the way, it becomes easier to identify diachronic change. For the remainder, he emphasizes that our focus should be on the history of diffusion, not on areas and boundaries.

Whether one applies the strict criteria for a Linguistic Area listed above or one follows Campbell's more inclusive definition, ${ }^{21}$ it appears that the features

17 Isoglosses are lines on a language map indicating where certain linguistic features occur.

18 If one wants to be finicky, the geographical dimension or "area" bit in the definition of Linguistic Area almost seems to be a consequence of the English translation. It is not inherent in the original terms used by Trubetzkoy, which were German Sprachbund 'federation [or union] of languages' and Russian Jazykovoy soyuz 'union of languages'.

19 My example.

${ }^{20}$ I am making this observation on the understanding that grammar includes phonology and phonetics.

${ }^{21}$ Note that, if taken to their extreme, Campbell's criteria of a Linguistic Area would also allow for one that consists of only two languages which are closely related and share only one contact feature. The occurrence of such an area is not hypothetical (nor is it likely to yield a fascinating 
shared by Banjar Malay, Ngaju, Ma'anyan, Malagasy, (and even Dusun Malang and Kadorih) ${ }^{22}$ fit in seamlessly with most of the proposed models. There are four languages (1) and four areal features (3) involved, and they all are of a phonological or grammatical nature. Possible doubts could be raised about points (2), (5), and (6), above, but they can be easily addressed. As far as (2) is concerned, although all languages compared in this article are Austronesian and even belong to the Malayo-Polynesian branch, they do represent three different lower-order subgroups (Malayic, West Barito, and Southeast Barito). Concerning (5), it is certainly the case that some of the defining features are not attested in all languages involved, whereas other such features spill over into languages outside of the Linguistic Area under discussion. However, it was also clear from the outset that the requirement of a neat bundling of shared features is unrealistic by itself, as shown in Campbell (2002). Of each of the features under discussion, at least three are shared among the four main languages which are part of the assumed Linguistic Area, and based on that score the latter is still a convincing proposition. Finally, in the case of (6), Campbell's arguments against the need for languages in a Linguistic Area to be contiguous are totally convincing. Moreover, in the case of Malagasy, this language might no longer be spoken in southern Borneo today, but it still was some thirteen centuries ago, and the features under discussion were already in operation at that time. In the context of these features, history is obviously in support of a past Linguistic Area configuration in southern Borneo which included Malagasy.

From Campbell's discussion it has become clear that the concept of Linguistic Area is of limited use to linguistic theory. It also lacks practical applicability in cases in which one Linguistic Area turns out to encroach upon another one, causing a situation in which its areal focus is diminished. The "areal" requirement is losing its relevance, especially since colonialism and in a globalizing world. Nevertheless, there is still some use for the concept, apart from enabling us to tease apart what is inherited and what is the consequence of contact (see above). Already for the sake of sheer reference, it has certainly benefited, say, sinologists working in mainland Southeast Asia to sort out the many commonalities between Chinese and the languages to its south (including Vietnamese, Muong, Burmese, and Thai), or linguists in Sri Lanka trying to work out the mutual influencing which has taken place between Sinhala, Tamil, and the local varieties of Malay and Portuguese. In the case of southern Borneo, it has the additional advantage that it gives us a historical perspective on the linguistic situation in southern Borneo before the migration of early Malagasy speakers to East Africa. In so doing, it contributes - no matter how modestly - to a better understanding of the migrations(s) of the Asian ancestors of the Malagasy to East Africa, which is one of the most

instance of a Linguistic Area ...).

${ }^{22}$ However, apart from the change from *s to $h$, these features do not surface in Samihim, which might be partly due to the circumstance that this dialect variant of Ma'anyan is underresearched. 
intriguing and at the same time least investigated events in the history of human migrations.

\section{CONCLUDING REMARKS}

Assuming that Linguistic Areas do not require to be geographically contiguous, Southern Borneo and Madagascar form a such an Area. It is based on evidence from four structural linguistic features that are manifested in Ngaju, Ma'anyan, Banjar Malay, and Malagasy. Given the weaknesses in the various definitions of the Linguistic Area concept (Campbell 2002), this conclusion is as likely to raise questions about the use of this concept as it is about the validity of the features involved.

While we admit that the concept is theoretically weak and that many of the issues involved can also be discussed without taking recourse to it, we also believe that there is still some use to it. As pointed out by Campbell (2002), it does help us to tease apart genetic and contact features. Moreover, in various cases it is also useful simply for the sake of reference. Finally, in the case of the southern Borneo linguistic area, it contributes in a modest way to a better understanding of the migration history of the Asian ancestors of the Malagasy to East Africa.

\section{ABBREVIATIONS}

$\begin{array}{ll}\text { ANAPH } & \text { anaphoric marker } \\ \text { ART } & \text { article } \\ \text { CAUS } & \text { causative } \\ \text { FOCUS } & \begin{array}{l}\text { focus particle } \\ \text { genetive }\end{array} \\ \text { GEN } & \text { involuntative } \\ \text { INVOL } & \text { locative voice } \\ \text { LV } & \text { nominalizer } \\ \text { NMZ } & \text { Proto Malayo-Polynesian } \\ \text { PMP } & \text { past tense } \\ \text { PST } & \text { reciprocal } \\ \text { REC } & \text { resultative } \\ \text { RESULT } & \text { undergoer voice and perfective aspect combined } \\ \text { UV.PERF } & \end{array}$

\section{REFERENCES}

Abdurachman Ismail, Abdul Kadir Ismail, Ahmad Aini, Muhammad Yusni, and Nazamuddin Nasufi. 1979. Bahasa Bukit. Jakarta: Pusat Pembinaan dan Pengembangan Bahasa (Departemen Pendidikan dan Kebudayaan). Abdul Djebar Hapip. 2006. Kamus Banjar Indonesia. Banjarmasin: Grafika Wangi Kalimantan.

Adelaar, Alexander. n.d. Ma' anyan fieldnotes (Central Kalimantan, Indonesia). Adelaar, Alexander. In press. "Seventeenth century texts as a key to Malagasy linguistic and ethnic history". [In a festschrift for XX, Delphine Burguet, Sarah Fee, and Samuel Sanchez (eds).] 
Adelaar, Alexander. 1989. "Malay influence on Malagasy; Historical and linguistic inferences", Oceanic Linguistics 28(1): 1-46.

Adelaar, Alexander. 1992. Proto-Malayic; The reconstruction of its phonology and parts of its morphology and lexicon. Canberra: Pacific Linguistics, Australian National University. [Pacific Linguistics C-119.]

Adelaar, Alexander. 2004. "Where does Malay come from? Twenty years of discussions about homeland, migrations and classifications", Bijdragen tot de Taal-, Land-en Volkenkunde 60(1): 1-29.

Adelaar, Alexander. 2017. "Who were the first Malagasy, and what did they speak?", in: Andrea Acri, Roger Blench, and Alexandra Landmann (eds), Spirits and ships; Cultural transfer in early monsoon Asia, pp. 441-469. Singapore: Institute of Southeast Asian Studies.

Blust, Robert A. (Online). Austronesian comparative dictionary. [Http:/ / trussel2. $\mathrm{com} / \mathrm{ACD} /]$.

Blust, Robert A. 2013. The Austronesian languages. Second edition. Canberra: College of Asia and the Pacific, The Australian National University. [AsiaPacific Open Access Monographs; Http:/ /hdl.handle.net/1885/10191].

Brucato, Nicolas, Pradiptajati Kusuma, Murray P. Cox, Denis Pierron, Harilanto Razafindrazaka, Gludhug Purnomo, Thierry Letellier, Toomas Kivisild, Alexander Adelaar, Herawati Sudoyo, and François-Xavier Ricaut. 2016. "Malagasy genetic ancestry comes from a historical Malay trading post in Southeast Borneo", Molecular Biology and Evolution 33(9): 2394-2400.

Campbell, Lyle. 2002. "Areal linguistics; A closer scrutiny”, in: Yaron Matras, April McMahon, Nigel Vincent (eds), Linguistic areas; Convergence in historical and typological perspective, pp. 1-31. London: Palgrave MacMillan.

Dahl, Otto Christian. 1951. Malgache et maanyan. Une comparaison linguistique. Avhandler utgitt av Egede-Instituttet. Oslo: Egede instituttet.

Gudai, Darmansyah H. 1985. A grammar of Maanyan, a language of Central Kalimantan. PhD thesis, Australian National University.

Gueunier, Noël J. (ed.). n.d. “Dictionnaire des dialectes malgaches du sud ouest (fondé sur le Dictionnaire sakalava-merina-français de victor Denis Mahavere [19251926], revu et complété par Noël J. Gueunier)“. [Unpublished.]

Hardeland, August. 1858. Versuch einer Grammatik der Ngadju-Dajackschen Sprache. Amsterdam: Frederik Muller.

Hardeland, August. 1859. Dajacksch - deutsches Wörterbuch. Amsterdam: Frederik Muller.

Houtman, Frederick de. 1603. Spraeck ende woord-boeck in de Maleysche ende Madagaskarsche talen, met vele Arabische ende Turcsche woorden ... : noch de Declinatien van vele vaste sterren, staende omtrent den Zuyd-pool. Amsterdam: J.Ez. Cloppenburch.

Hudson, Alfred B. 1967. The Barito isolects of Borneo. Ithaca, NY: Cornell University Press. [Southeast Asia Program, Department of Asian Studies, Data Paper No. 68.] 
Inagaki, Kazuya. 2006. "A sketch on the morphosyntax of Kadorih", Kyoto University Linguistic Research 25: 41-65.

Inagaki, Kazuya. 2008. Kadorih; Description of an Austronesian language of Borneo. $\mathrm{PhD}$ thesis, Kyoto University.

Kern, W. n.d. "Dutch and Banjarese wordlist". [W. Kern's notes on the language and literature of Banjar; unpublished.]

Nothofer, Bernd. 1995. "The history of Jakarta Malay", Oceanic Linguistics 34(1): 86-97.

Ras, J.J. 1968. Hikajat Banjar; A study in Malay historiography. The Hague: Martinus Nijhoff.

Rasoloson, Janie and Carl Rubino. 2011. "Malagasy", in: Alexander Adelaar and Nikolaus P. Himmelmann (eds), The Austronesian languages of Southeast Asia and Madagascar, pp. 456-488. London: Routledge. [Second edition; First edition 2005.]

Rubay G.S., Adjin Widen, Pagoe Bangel, C.Dj. Bandrang, Apria Dansen, and C. Yus Ngabut. 1997. Kamus bahasa Ma'anyan Edisi II. Palangkaraya: Proyek Pembinaan Perpustakaan Umum Dati II.

Sellato, Bernard. 2013. "Settlement, migration, and trade along river axes in Borneo". [Paper, Seventh EUROSEAS Conference, Lisbon, 2-6 July.]

Stokhof, W.A.L. (ed.), in co-operation with Alma E. Almanar. 1986. Holle lists; Vocabularies in languages of Indonesia Vol. 8: Kalimantan (Borneo). Canberra: Pacific Linguistics, Australian National University. [Materials in Languages of Indonesia No. 31, PL D-69.]

Sundermann, H.H. 1913. “Der Dialekt der 'olon Maanyan' (Dajak) in Süd-ostBorneo", Bijdragen tot de Taal-, Land-en Volkenkunde van Nederlandsch-Indië 66: 169-189.

Tjia, Johnny. n.d. Fieldnotes of Dusun Malang (Central Kalimantan, Indonesia). Trubetzkoy, Nikolai S. 1923. "The tower of Babel and the confusion of languages" ["Vavilonskaja bašnja i smešenie jazykov"], Evrazijskij vremennik, 3: 107-124. Wilkinson, R.J. 1959. A Malay-English dictionary (Romanised). London: Macmillan. 